\title{
Suboptimal health: a potential preventive instrument for non-communicable disease control and management
}

Wei Wang ${ }^{1,2,3}$

\author{
From 2012 Sino-American Symposium on Clinical and Translational Medicine (SAS-CTM) \\ Shanghai, China. 27-29 June 2012
}

Suboptimal health status (SHS) is characterized by ambiguous health complaints, general weakness, and lack of vitality, and it has become a new public health challenge in China [1,2]. SHS is believed to be a subclinical, reversible stage of chronic disease. As studies of intervention and prognosis for SHS are expected to become increasingly important, a reliable and valid instrument for its assessment is essential. A questionnaire for measuring SHS in urban Chinese was developed based on focus group discussions and a literature review [1]. Questionnaire validity and reliability were evaluated in a small pilot study and then in a cross-sectional study of 3000 individuals [2]. The analyses included tests for reliability and internal consistency, exploratory and confirmatory factor analysis, and tests for discriminative ability and convergent validity. The final questionnaire incorporated 25 items on SHS (SHSQ25), and encompassed 5 subscales: fatigue, cardiovascular system, digestive tract, immune system, and mental status $[1,2]$. The SHSQ-25 has proved to be a reliable and valid instrument for measuring sub-health status in urban Chinese [2]. The progress of a combined genomics and glycomics study for screening biomarkers and exploring SHS as a preventive tool for non-communicable disease control and management will be presented [3].

\footnotetext{
Author details

'School of Medical Science, Edith Cowan University, Perth, Australia.

${ }^{2}$ Graduate School, Chinese Academy of Sciences, Beijing, China. ${ }^{3}$ School of

Public Health and Family Medicine, Capital Medical University, Beijing, China.
}

Published: 17 October 2012

\section{References}

1. Yan YX, Liu YQ, Li M, Hu PF, Guo AM, Yang XH, Qiu JJ, Yang SS, Wang W: Development and evaluation of a questionnaire for measuring suboptimal health status in urban Chinese. Journal of Epidemiology 2009, doi:10.2188/jea.JE20080086.

2. Yan YX, Do J, Liu YQ, Yang XH, Li M, Xia G, Wang W: Association of suboptimal health status and cardiovascular risk factors in urban Chinese workers. Journal of Urban Health 2012, doi10.1007/s11524-0119636-8.

3. Lu JP, Knezevic A, Wang YX, Rudan I, Campbell H, Zou ZK, Lan J, Lai QY, Wu JJ, He Y, Song MS, hang L, Lauc G, Wang W: Screening novel biomarkers for metabolic syndrome by profiling human plasma $\mathrm{N}$-glycans in Chinese Han and Croatian populations. Journal of Proteome Research 2011, 10(11):4959-4969.

doi:10.1186/1479-5876-10-S2-A45

Cite this article as: Wang: Suboptimal health: a potential preventive instrument for non-communicable disease control and management. Journal of Translational Medicine 2012 10(Suppl 2):A45.

Correspondence: wei.wang@ecu.edu.au

${ }^{1}$ School of Medical Science, Edith Cowan University, Perth, Australia

Full list of author information is available at the end of the article

Submit your next manuscript to BioMed Central and take full advantage of:

- Convenient online submission

- Thorough peer review

- No space constraints or color figure charges

- Immediate publication on acceptance

- Inclusion in PubMed, CAS, Scopus and Google Scholar

- Research which is freely available for redistribution
() Biomed Central 